\title{
STRUCTURAL CHARACTERISTICS OF CORDIERITES BASED ON COMMERCIAL VERMICULITES IN RELATION TO THE NATURAL AND SYNTHETIC CORDIERITES
}

\author{
MARTA VALÁŠKOVÁ \\ Nanotechnology Centre, V̌̌B - Technical University of Ostrava, \\ 17. listopadu 15/2172, CZ-708 33 Ostrava-Poruba, Czech Republic \\ "E-mail: marta.valaskova@vsb.cz
}

Submitted June 2, 2016; accepted July 28, 2016

\begin{abstract}
Keywords: Vermiculite, Cordierite, Indialite, X-ray diffraction, Structural ordering
The preparation and characterization of cordierites based on the commercial vermiculites obtained from the powder preceramic mixtures containing talc, kaolinite and vermiculite in the composition close to the cordierite $2 \mathrm{MgO}_{2} \cdot \mathrm{Al}_{2} \mathrm{O}_{3} \cdot 5 \mathrm{SiO}_{2}$ has been reported since 2009. The aim of this paper was to characterize the structural properties of the nine synthetic cordierites sintered from the pre-ceramic mixtures containing commercial vermiculites at $1300^{\circ} \mathrm{C}$, in comparison with the orthorhombic natural and synthetic hexagonal cordierites (indialites) selected from literature. The orthorhombic natural cordierites showed the elements $\mathrm{Fe}$ and $\mathrm{Mn}$ replacing $\mathrm{Mg}$ in an appropriate correlation $\mathrm{F}=(\mathrm{Fe}+\mathrm{Mn}) /(\mathrm{Fe}+\mathrm{Mn}+\mathrm{Mg})$ with the unit cell parameter $a$, and an inverse correlation with parameter $c$. The unit cell parameters $c$ calculated for the nine synthetic cordierites based on vermiculites (Ver) were in good linear relation with the $F_{V e r}=\left(\mathrm{Fe} /(\mathrm{Fe}+\mathrm{Mg})_{\text {oct }}+(\mathrm{K}+\mathrm{Na}+\mathrm{Ca})\right.$ int) per formula unit of the corresponding vermiculites in the pre-ceramic mixtures. The structural disorder of cordierites based on vermiculites was determined higher, according to the wide index W1/3 of (211) reflection varying in a narrow range $W 1 / 3_{(211)}$ from $0.290^{\circ}$ to $0.299^{\circ} 2 \theta$, in comparison with the $W 1 / 3_{(211)}=0.324^{\circ} 2 \theta$ of the cordierites based on the alumina.
\end{abstract}

\section{INTRODUCTION}

The cordierite glass-ceramics based on $\mathrm{MgO}-\mathrm{SiO}_{2}-$ $-\mathrm{Al}_{2} \mathrm{O}_{3}$ crystalline system are widely used due to their excellent mechanical properties, low dielectric constant and low coefficient of thermal expansion. The earliest physicochemical investigation of the system $\mathrm{MgO}-$ $-\mathrm{Al}_{2} \mathrm{O}_{3}-\mathrm{SiO}_{2}$ brought information about the $\alpha$ form of cordierite $2 \mathrm{MgO}: 2 \mathrm{Al}_{2} \mathrm{O}_{3}: 5 \mathrm{SiO}_{2}(2: 2: 5)$ and an unstable $\mu$-cordierite modification of cordierite $\mathrm{MgO}: \mathrm{Al}_{2} \mathrm{O}_{3}: 3 \mathrm{SiO}_{2}$ (1:1:3) [1]. A natural analogue of $\alpha$ form was cordierite subsequently discovered in India and named indialite [2]. The crystal structure of indialite is isotypic with that of hexagonal beryl [3-5].

Cordierite aluminosilicate $\mathrm{Al}_{4} \mathrm{Si}_{5} \mathrm{O}_{18}$ framework consists from tetrahedra $\left(\mathrm{Al}^{3+}, \mathrm{Si}^{4+}\right) \mathrm{O}_{4}$ and octahedra $\left(\mathrm{Mg}^{2+}, \mathrm{Fe}^{2+}\right) \mathrm{O}_{6}$ interspersed with channels that can contain larger molecules (e.g., $\mathrm{H}_{2} \mathrm{O}, \mathrm{CO}_{2}$ ) or cations (e.g. $\mathrm{Na}^{+}, \mathrm{Cs}^{+}$). $\mathrm{Mg}$-cordierite, $\mathrm{Mg}_{2} \mathrm{Al}_{4} \mathrm{Si}_{5} \mathrm{O}_{18}$, crystallizes in two polymorphic forms: the high-temperature disordered hexagonal form (space group $\mathrm{P} 6 / \mathrm{mmc}$ ), stable above about $1450^{\circ} \mathrm{C}$ and the low-temperature slightly disordered orthorhombic form (space group $\mathrm{Cccm}$ ), stable below $1450^{\circ} \mathrm{C}$ [6-8]. In the high-temperature hexagonal structure the $\mathrm{Al}$ and $\mathrm{Si}$ atoms are distributed over two sets of tetrahedral sites ( $3 \mathrm{~T} 1$ and $6 \mathrm{~T} 2$ sites per formula unit). The refined structure of indialite has a disordered distribution of $2 \mathrm{Al}$ and $1 \mathrm{Al}$ atoms over $\mathrm{T} 1$ sites and $2 \mathrm{Al}$ and $4 \mathrm{Si}$ disordered over $\mathrm{T} 2$ site [8-10]. During Al, Si ordering an opposite pair of T2 tetrahedra are occupied by the $2 \mathrm{Al}$ atoms and symmetry is reduced to orthorhombic with the space group $\mathrm{Cccm}$ (Figure 1). The relationship between the hexagonal and orthorhombic unit cells (Figure 1a), which could form from the hexagonal structure, can be performed at three equivalent orientations of the orthorhombic unit cell (Figure 1b) [11].

The structural transformations of $\mathrm{Al}, \mathrm{Si}$ orderdisorder were studied on the high- (hexagonal), intermediate- (modulated hexagonal) and low-(orthorhombic) cordierites [7, 12-14]. An intermediate crystal phases are of either the indialite or cordierite between the highest disorder and a rather high degree of order. Miyashiro [5] used a distortion index $\Delta=2 \theta_{(131)}-\left(2 \theta_{(511)}+2 \theta_{(421)}\right) / 2$, as a measure of the degree of disorder which is defined by the X-ray diffraction (XRD) angles in the region between $2 \theta=29$ and $30^{\circ}$ ( $\mathrm{CuK} \alpha$ radiation) for the orthorhombic peaks (131), (511) and (421) in the powder XRD patterns. Distortion indices $\Delta$ describing the state of advancement of the hexagonal to orthorhombic transition are in a range from 0.0 in hexagonal cordierite to about 0.25 in fully ordered, orthorhombic Mg-cordierite. 


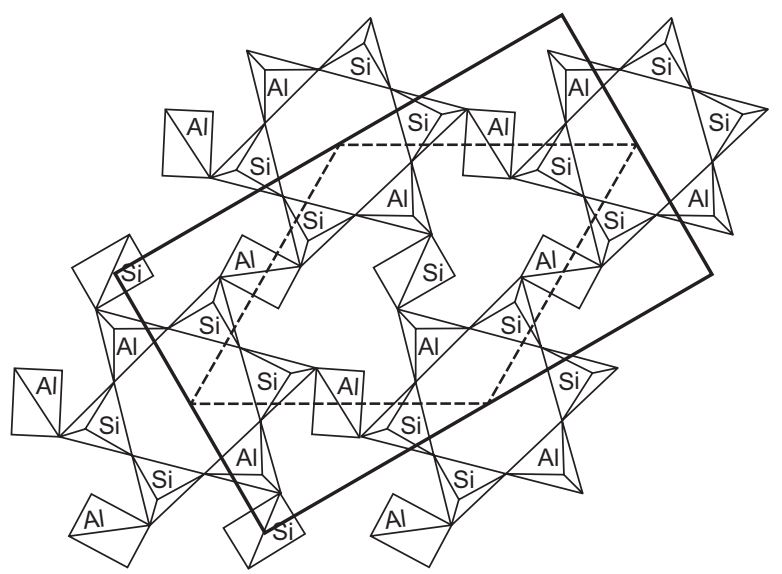

a)

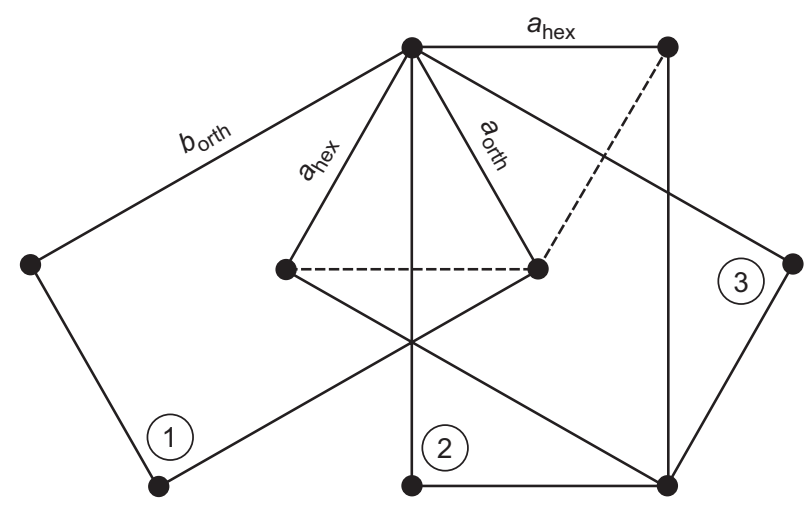

b)

Figure 1. Geometry of the cordierite structures: a) The orthorhombic unit cell of the ordered structure (full line) and the hexagonal unit cell of the disordered cordierite structure (dashed line); b) Three equivalent orientations of the orthorhombic unit cell derived from the hexagonal unit cell [11].

Natural cordierites occur mostly as ( $\mathrm{Si}, \mathrm{Al})$-ordered orthorhombic low-cordierites with minor amounts of alkaline earth and alkali metal elements [7] and occasionally as hexagonal high-cordierites, indialites, with a less ordered (Si,Al)-arrangement [8]. Substitution of the large cations $\mathrm{Mg}^{2+}$ and $\mathrm{Fe}^{2+}$ for $\mathrm{Al}^{3+}$ is sustained by the decreasing average size of the octahedral cation. Tetrahedral substitution of $\mathrm{Fe}^{2+}$ up to $11 \%$ in $\mathrm{Fe}, \mathrm{Mg}$-cordierites was assessed by Mössbauer spectroscopy [15].

Synthetic hexagonal cordierites were found at low temperatures in glass ceramics. The synthetic indialite was obtained from the melts at the high temperatures as the component of solid solutions of $\mathrm{Mg}$-cordierite $\left(\mathrm{Mg}_{2} \mathrm{Al}_{4} \mathrm{Si}_{5} \mathrm{O}_{18}\right)$ - Mg-beryl $\left(\mathrm{Mg}_{3} \mathrm{Al}_{2} \mathrm{Si}_{6} \mathrm{O}_{18}\right)$ [16]. Longer annealing of this system in the low-temperature region, which occurs at about $1300^{\circ} \mathrm{C}$, resulted in the breakdown of the solid solutions and the separation of cordierite in the stoichiometric composition $2 \mathrm{MgO} \cdot 2 \mathrm{Al}_{2} \mathrm{O}_{3} \cdot 5 \mathrm{SiO}_{2}$. The solid solutions of cordierite, which may be considered as metastable form at lower temperatures $\left(1250^{\circ} \mathrm{C}\right)$ remain at very low temperatures $\left(1050^{\circ} \mathrm{C}\right)$ unchanged for more than a year [16]. Disordered high cordierite also crystallizes as a metastable phase from all temperatures below $1455^{\circ} \mathrm{C}$ and be retained by quenching [17].

Most clay minerals and clays, alone or in mixtures, are used for their contribution to the working properties and drying strength of the ceramic masses [18]. Some of clays are applied more because they offer an inexpensive integral component or filler of the desired chemical composition. Natural clay materials used in preparing of ceramics include impurities of alkali oxides and alkaline earth oxides. These admixtures together with the layered structure of clay minerals facilitate structural changes in a relatively low temperature annealing.

Vermiculite is a secondary 2:1 clay mineral formed primarily alteration of micas (biotite and phlogopite). At all the major commercial deposits, natural vermiculites occur as the mixed-layer vermiculite-biotites or vermiculite-phlogopites [19-21]. The commercial vermiculites from Sta. Olalla (Huelva, Spain), Catalão (Goiás, Brasil), China and Palabora (South Africa) were examined at elevated temperatures for the thermal transformation [22]. Vermiculites containing the principal cations $\mathrm{K}^{+}$, $\mathrm{Na}^{+}$and $\mathrm{Ca}^{2+}$ in the interlayer space transformed at $1000^{\circ} \mathrm{C}$ during $1 \mathrm{~min}$ to mica-like or mica-like phases coexisting with enstatite. Vermiculite from Sta. Olalla, containing only $\mathrm{Mg}^{2+}$ in the interlayer space, changed to enstatite.

Vermiculites are well-known for their water-retention properties. Porous ceramics with good waterretention properties were prepared from mixtures of ground vermiculite with allophane at $600-800^{\circ} \mathrm{C}$ [23]. The exchangeable $\mathrm{Mg}^{2+}$ cations in $\mathrm{Mg}$-saturated vermiculite structure, $\mathrm{Mg}_{3}\left(\mathrm{Si}_{3} \mathrm{Al}\right) \mathrm{O}_{10}(\mathrm{OH})_{2} \cdot \mathrm{Mg}_{0.5}\left(\mathrm{H}_{2} \mathrm{O}\right)_{4.0}$, lie in a plane midway between 2:1 layers and have a plane of water molecules on each side. Each water molecule is linked by a hydrogen bond to single oxygen in the silicate layer surface and the water sheets are held together by the exchangeable cations [24]. An isomorphous substitution of metal cations with similar size and lower valence, such as $\mathrm{Si}^{4+}-\mathrm{Al}^{3+}$ (in tetrahedra) and $\mathrm{Al}^{3+}-\mathrm{Mg}^{2+}$ (in octahedra) creates a net negative charge of 2:1 layers [25]. The negative layer charge, which arises mostly from the substitution of $\mathrm{Al}^{3+}$ for $\mathrm{Si}^{4+}$ in tetrahedral sites, is between 0.6 and $0.9 \mathrm{eq} /(\mathrm{Si}, \mathrm{Al})_{4} \mathrm{O}_{10}$. Several observations suggest that vermiculitization is not the final stage of alteration. A continuous process of micavermiculite-smectite alteration results in vermiculites that show a smectite charge. The characteristic properties of vermiculite (e.g., the high cation exchange capacity, the ability to form complexes with organic substances, depending on the exchangeable cations and the humidity) are suitable for modifying of vermiculite precursors into the cordierite ceramics with specifics properties. During the last five years, vermiculites were prepared 
into the powder mixtures as: (1) The cation exchanged zirconium-vermiculite precursor of zircon $\left(\mathrm{ZrSiO}_{4}\right)$ in dense cordierite- $\mathrm{ZrSiO}_{4}$ ceramics [26, 27], (2) The carrier of an anchored ceria $\left(\mathrm{CeO}_{2}\right)$ nanoparticles precipitated on the negative surface for the cordierite/steatite $/ \mathrm{CeO}_{2}$ photocatalysts [28], and (3) Organovermiculite poreforming additive to the porous cordierite ceramics [29].

The aim of the work is to compare the structural data of the cordierites based on vermiculite prepared from the powder mixtures containing commercial vermiculites in the stoichiometric oxides composition close to the cordierite composition $2 \mathrm{MgO} \cdot 2 \mathrm{Al}_{2} \mathrm{O}_{3} \cdot 5 \mathrm{SiO}_{2}$ with the data of the published selected natural and synthetic cordierites.

\section{EXPERIMENTAL}

The clay minerals kaolinite, $\mathrm{Ka}$, (from $\mathrm{LB}$ Minerals, s.r.o., Czech Republic), talc KT5, Tc, (from Koltex Color, s.r.o., Czech Republic) and commercial vermiculites (Grena, s.r.o., Czech Republic) were used for preparation of the pre-ceramic cordierite mixtures. Five natural vermiculite samples prepared by milling and then sieving to the particles size fraction less than $0.40 \mu \mathrm{m}$ were denoted as Ver-L, Ver-B, Ver-S, Ver-P and Ver-C.
Ver-L from the Letovice crystalline complex in the eastern part of the Bohemian Massif (Czech Republic) is a product of transformation of $\mathrm{Mg}$-chlorites in metamorphosed basalts, as well as gabbroic and ultrabasic bodies.

Ver-B from Belitsa, northwestern region of Bulgaria, was found in calc-alkaline rocks, biotite-hornblende granodiorites and tonalities, that apparently has resulted from the action of rain water on the biotite and phlogopite [30].

Ver-S from the Paraiba region of Brazil occurs in the Santa Luzia mine mainly within zones of complex mafic, ultramafic and carbonatite after transformation of phlogopite and biotite [31].

Ver-P from Palabora mine in the Limpopo province of South Africa occurring in the phlogopite- and apatiterich pyroxenites is a product of hydration of phlogopite into vermiculite. This vermiculite was described as mixed-layer vermiculite-phlogopite, with the content of vermiculite less than $50 \%$ [32].

Ver-C from the Qieganbulak apatite-vermiculite deposit in Xinjiang Yuli Xinlong (China) is the weathering product of phlogopite from a basic-ultrabasic complex [33].

The chemical composition of commercial vermiculites (Table 1) was determined using the X-ray fluorescence spectrometer Spectro X-lab [26-29]. The

Table 1. Chemical analysis of commercial vermiculites, kaolinite and talc and cations in structural formulae of vermiculites.

\begin{tabular}{|c|c|c|c|c|c|c|c|}
\hline Oxides & Ver-L & Ver-B & Ver-P & Ver-S & Ver-C & $\mathrm{Ka}$ & $\mathrm{Tc}$ \\
\hline $\mathrm{SiO}_{2}$ & 32.00 & 41.15 & 41.25 & 43.34 & 40.16 & 46.13 & 60.22 \\
\hline $\mathrm{TiO}_{2}$ & 0.50 & 0.41 & 1.03 & 0.85 & 1.07 & 0.19 & 0.00 \\
\hline $\mathrm{Al}_{2} \mathrm{O}_{3}$ & 14.51 & 9.98 & 8.75 & 10.83 & 12.40 & 37.28 & 0.60 \\
\hline $\mathrm{Fe}_{2} \mathrm{O}_{3}$ & 7.91 & 5.36 & 5.06 & 6.14 & 4.31 & 0.77 & 0.19 \\
\hline $\mathrm{FeO}$ & 0.26 & 0.79 & 1.25 & 0.46 & 0.47 & 0.00 & 0.00 \\
\hline $\mathrm{CaO}$ & 0.18 & 1.46 & 2.43 & 1.30 & 2.16 & 0.32 & 0.73 \\
\hline $\mathrm{MgO}$ & 22.25 & 23.22 & 23,48 & 23.23 & 23.88 & 0.43 & 31.55 \\
\hline $\mathrm{MnO}$ & 0.11 & 0.05 & 0.06 & 0.10 & 0.04 & 0.00 & 0.00 \\
\hline $\mathrm{Na}_{2} \mathrm{O}$ & 0.02 & 0.19 & 0.15 & 0.35 & 0.46 & 0.00 & 0.00 \\
\hline $\mathrm{K} 2 \mathrm{O}$ & 0.06 & 0.48 & 4.81 & 1.82 & 3.55 & 0.65 & 0.01 \\
\hline LOI & 21.56 & 16.70 & 11.47 & 11.40 & 10.98 & 14.14 & 6.24 \\
\hline Total & 99.36 & 99.79 & 99.74 & 99.82 & 99.48 & 99.91 & 99.54 \\
\hline Ions p.f.u* & Ver-L & Ver-B & Ver-P & Ver-S & Ver-C & & \\
\hline $\mathrm{Si}$ & 2.65 & 3.15 & 3.10 & 3.14 & 2.95 & & \\
\hline $\mathrm{Al}^{\mathrm{IV}}$ & 1.35 & 0.85 & 0.78 & 0.86 & 1.05 & & \\
\hline $\mathrm{Fe}$ & - & - & 0.12 & - & - & & \\
\hline $\mathrm{Al}^{\mathrm{VI}}$ & 0.06 & 0.05 & - & 0.06 & 0.03 & & \\
\hline $\mathrm{Fe}^{3+}$ & 0.49 & 0.31 & 0.23 & 0.33 & 0.24 & & \\
\hline $\mathrm{Fe}^{2+}$ & 0.02 & 0.05 & 0.08 & 0.04 & 0.03 & & \\
\hline $\mathrm{Mg}$ & 2.40 & 2.57 & 2.64 & 2.52 & 2.64 & & \\
\hline $\mathrm{Ti}$ & 0.03 & 0.02 & 0.05 & 0.05 & 0.06 & & \\
\hline $\mathrm{K}$ & 0.01 & 0.05 & 0.45 & 0.15 & 0.33 & & \\
\hline $\mathrm{Na}$ & 0.01 & 0.02 & 0.02 & 0.02 & 0.05 & & \\
\hline $\mathrm{Ca}$ & 0.02 & 0.12 & 0.10 & 0.10 & 0.16 & & \\
\hline $\mathrm{Mg}$ & 0.34 & 0.07 & - & - & - & & \\
\hline
\end{tabular}

* 10 structural oxygens plus two $\mathrm{OH}$ and a total negative charge of 22 per formula unit 
samples were mixed with the wax and pressed into the form of pellets. The concentration of $\mathrm{Na}^{+}, \mathrm{K}^{+}, \mathrm{Mg}^{2+}$ and the total content of the $\mathrm{Fe}^{2+}$ and $\mathrm{Fe}^{3+}$ was also determined using the atomic emission spectrometer JY 24 with inductively coupled plasma (ICP-AES) after total sample dissolution in $\mathrm{HCl}$ and $\mathrm{HF}$ and acid mixture $\left(\mathrm{H}_{3} \mathrm{PO}_{4}+\mathrm{H}_{2} \mathrm{SO}_{4}+\mathrm{H}_{3} \mathrm{BO}_{3}\right)$. The content of $\mathrm{Fe}^{2+}$ was determined using titration with $0.1 \mathrm{M}$ solution of $\mathrm{K}_{2} \mathrm{Cr}_{2} \mathrm{O}_{7}$ after sample decomposition in $\mathrm{HCl}$ and $\mathrm{HF}$ in a $\mathrm{CO}_{2}$ atmosphere, according to the Czech standard CSN 722041 Part 11. The loss on ignition was determined by heating of samples in muffle furnace at $1000^{\circ} \mathrm{C}$. The chemical composition of vermiculites was recalculated into structural formulae using a basis of 10 structural oxygens plus two $\mathrm{OH}$ and a total negative charge of 22 per formula unit, p.f.u (Table 1).

The X-ray powder diffraction (XRD) patterns of cordierite ceramic samples were recorded in the $5-80^{\circ} 2 \theta$ range with a scanning rate of $2^{\circ} \cdot \mathrm{min}^{-1}$ using the X-ray diffractometer Ultima IV Rigaku (Rigaku, Japan), operated at $40 \mathrm{kV}$ and $40 \mathrm{~mA}$ with $\mathrm{CuK \alpha}$ radiation (reflection mode, scintillation counter). The unit cell parameters of cordierites were calculated by a least squares refinement program [34] using the interlayer $d$-values and assigned $\mathrm{h} \mathrm{k} 1$ indices.

\section{Cordierites based on the vermiculite} in mixtures

A basic clay mixture for sintering cordierite, which is often used in scientific research and industry, is composed of talc $\left(\mathrm{Mg}_{3} \mathrm{Si}_{4} \mathrm{O}_{10}\right)(\mathrm{OH})_{2}$, kaolinite $\left(\mathrm{Si}_{2} \mathrm{Al}_{2} \mathrm{O}_{5}\right)$ $(\mathrm{OH})_{4}$ and alumina $\left(\mathrm{Al}_{2} \mathrm{O}_{3}\right)$. Vermiculite from Czech Republic (named Ver-L) was added to the basic clay mineral mixtures in an amount from 13 to $50 \mathrm{wt}$ \%

Table 2. Structures of selected natural and synthetic cordierites according to literature.

\begin{tabular}{|c|c|c|}
\hline No. & Host rock, Locality [Reference] & Formula \\
\hline \multicolumn{3}{|c|}{ Orthorhombic natural cordierites (space group Cccm) } \\
\hline & \multicolumn{2}{|l|}{ The Bergell region in the Central Alps [36] } \\
\hline 1. & Inclusion in tonalite & $\left(\mathrm{Mg}_{1.86} \mathrm{Fe}_{0.14}\right) \mathrm{Al}_{4.03} \mathrm{Si}_{4.98} \mathrm{O}_{18}$ \\
\hline 2. & Pelitic zone & $\left(\mathrm{Mg}_{1.79} \mathrm{Fe}_{0.19}\right) \mathrm{Al}_{4.02} \mathrm{Si}_{5.00} \mathrm{O}_{18}$ \\
\hline 3. & Cordierite-garnet-biotite-gneiss & $\left(\mathrm{Mg}_{1.72} \mathrm{Fe}_{0.27}\right) \mathrm{Al}_{4.00} \mathrm{Si}_{5.00} \mathrm{O}_{18}$ \\
\hline 4. & Cordierite-K feldspar-biotite gneiss & $\left(\mathrm{Mg}_{1.36} \mathrm{Fe}_{0.64}\right) \mathrm{Al}_{4.03} \mathrm{Si}_{4.98} \mathrm{O}_{18}$ \\
\hline 5. & Inclusion zone in Bergell granite & $\left(\mathrm{Mg}_{1.19} \mathrm{Fe}_{0.73}\right) \mathrm{Al}_{4.03} \mathrm{Si}_{5.01} \mathrm{O}_{18}$ \\
\hline \multirow[t]{2}{*}{6.} & Contact of Bergell granite & $\left(\mathrm{Mg}_{1.11} \mathrm{Fe}_{0.80}\right) \mathrm{Al}_{4.01} \mathrm{Si}_{5.03} \mathrm{O}_{18}$ \\
\hline & \multicolumn{2}{|l|}{ Tuscany, Italy [9] } \\
\hline 7. & "Torniella" cordierite from a rhyolite & $\left(\mathrm{Mg}_{1.12} \mathrm{Fe}_{0.82} \mathrm{Mn}_{0.02}\right) \mathrm{Al}_{4.02} \mathrm{Si}_{4.99} \mathrm{O}_{18}$ \\
\hline 8. & San Vincenzo Cordierite from a rhyodacite & $\left(\mathrm{Mg}_{0.95} \mathrm{Fe}_{1.09} \mathrm{Mn}_{0.03}\right) \mathrm{Al}_{3.91} \mathrm{Si}_{5.03} \mathrm{O}_{18}$ \\
\hline 9. & "Lipari" nodule. Cordierite from rhyodacite & $\left(\mathrm{Mg}_{0.90} \mathrm{Fe}_{1.12} \mathrm{Mn}_{0.03}\right) \mathrm{Al}_{4.00} \mathrm{Si}_{5.00} \mathrm{O}_{18}$ \\
\hline \multirow[t]{2}{*}{10.} & "Lipari" crystal. Cordierite from rhyodacite. & $\left(\mathrm{Mg}_{1.17} \mathrm{Fe}_{0.86} \mathrm{Mn}_{0.02}\right) \mathrm{Al}_{3.96} \mathrm{Si}_{5.00} \mathrm{O}_{18}$ \\
\hline & \multicolumn{2}{|l|}{ Other natural cordierites [37] } \\
\hline 11. & White Well, Western Australia & $\left(\mathrm{Mg}_{1.88} \mathrm{Fe}_{0.09} \mathrm{Na}_{0.05}\right) \mathrm{Al}_{3.96} \mathrm{Si}_{4.94} \mathrm{O}_{18}$ \\
\hline 12. & Casper, Wyoming & $\left(\mathrm{Mg}_{1.76} \mathrm{Fe}_{0.23} \mathrm{Na}_{0.04}\right) \mathrm{Al}_{4.00} \mathrm{Si}_{5.00} \mathrm{O}_{18}$ \\
\hline 13. & SN2229 from metapelite, Labrador & $\left(\mathrm{Mg}_{1.67} \mathrm{Fe}_{0.32} \mathrm{Mn}_{0.02} \mathrm{Na}_{0.02}\right) \mathrm{Al}_{4.00} \mathrm{Si}_{5.00} \mathrm{O}_{18}$ \\
\hline 14. & Guilford from pegmatite vein & $\left(\mathrm{Mg}_{1.55} \mathrm{Fe}_{0.45} \mathrm{Mn}_{0.02} \mathrm{Na}_{0.07}\right) \mathrm{Al}_{4.00} \mathrm{Si}_{5.00} \mathrm{O}_{18}$ \\
\hline 15. & Pielosca, Finland & $\left(\mathrm{Mg}_{1.46} \mathrm{Fe}_{0.55} \mathrm{Mn}_{0.01} \mathrm{Na}_{0.03}\right) \mathrm{Al}_{4.00} \mathrm{Si}_{5.00} \mathrm{O}_{18}$ \\
\hline 16. & Haddam, Connecticut & $\left(\mathrm{Mg}_{1.34} \mathrm{Fe}_{0.58} \mathrm{Mn}_{0.02} \mathrm{Na}_{0.27}\right) \mathrm{Al}_{4.00} \mathrm{Si}_{5.00} \mathrm{O}_{18}$ \\
\hline 17. & Ghost Lake, Canada & $\left(\mathrm{Mg}_{1.21} \mathrm{Fe}_{0.77} \mathrm{Na}_{0.03}\right) \mathrm{Al}_{4.00} \mathrm{Si}_{5.00} \mathrm{O}_{18}$ \\
\hline 18. & SN72123, Labrador & $\left(\mathrm{Mg}_{0.86} \mathrm{Fe}_{1.12} \mathrm{Na}_{0.02}\right) \mathrm{Al}_{4.00} \mathrm{Si}_{5.00} \mathrm{O}_{18}$ \\
\hline 19. & Sugama, Japan & $\left(\mathrm{Mg}_{0.49} \mathrm{Fe}_{1.17} \mathrm{Mn}_{0.20} \mathrm{Na}_{0.33}\right) \mathrm{Al}_{4.00} \mathrm{Si}_{5.00} \mathrm{O}_{18}$ \\
\hline 20. & Dolni Bory, Czechoslovakia & $\left(\mathrm{Mg}_{0.19} \mathrm{Fe}_{1.61} \mathrm{Mn}_{0.08} \mathrm{Na}_{0.20}\right) \mathrm{Al}_{4.00} \mathrm{Si}_{5.00} \mathrm{O}_{18}$ \\
\hline \multicolumn{3}{|c|}{ Hexagonal cordierites(space group P6/mcc) } \\
\hline & \multicolumn{2}{|l|}{ Natural indialites } \\
\hline 21. & Indialite from xenolithic rocks, Italy [38] & $\left(\mathrm{K}_{0.17} \mathrm{Mg}_{1.94} \mathrm{Fe}_{0.06} \mathrm{Ca}_{0.04}\right) \mathrm{Al}_{4.25} \mathrm{Si}_{4.75} \mathrm{O}_{18}$ \\
\hline 22. & Indialite from coal seam, India [8] & $\left(\mathrm{Mg}_{1.40} \mathrm{Fe}_{0.66}\right) \mathrm{Al}_{4.11} \mathrm{Si}_{4.89} \mathrm{O}_{18}$ \\
\hline \multirow[t]{2}{*}{23.} & Indialite from cordierite gneisses, India [39] & $\left(\mathrm{Mg}_{1.38} \mathrm{Fe}_{0.63} \mathrm{Mn}_{0.05} \mathrm{Ca}_{0.25}\right) \mathrm{Al}_{4.72} \mathrm{Si}_{4.19} \mathrm{O}_{18}$ \\
\hline & \multicolumn{2}{|l|}{ Synthetic cordierites } \\
\hline 24. & Cordierite from the gel [40] & $\mathrm{Mg}_{2.00} \mathrm{Al}_{4.00} \mathrm{Si}_{5.00} \mathrm{O}_{18}$ \\
\hline 25. & Cordierite from glass [41] & $\mathrm{Mg}_{2.00} \mathrm{Al}_{4.00} \mathrm{Si}_{5.00} \mathrm{O}_{18}$ \\
\hline 26. & Cordierite from glass [42] & $\mathrm{Mg}_{2.00} \mathrm{Al}_{4.00} \mathrm{Si}_{5.00} \mathrm{O}_{18}$ \\
\hline
\end{tabular}


with the simultaneous adjustment of the other incorporated minerals, while maintaining close to cordierite composition $2 \mathrm{MgO} \cdot 2 \mathrm{Al}_{2} \mathrm{O}_{3} \cdot 5 \mathrm{SiO}_{2}[26,35]$. Cordierites named here as $\mathrm{X} 1-\mathrm{X} 4$ were prepared from the powder mixtures containing variable representation of talc, kaolinite, alumina and vermiculite (in mass \%) as follows:

$\mathrm{X} 1$ : talc (40), kaolinite (47), alumina, $\mathrm{Al}_{2} \mathrm{O}_{3}(13)$ [35].

$\mathrm{X} 2$ : talc (30), kaolinite (45), vermiculite (12) and alumina (13) [35].

X3: talc (20), kaolinite (50), vermiculite (30) [26].

X4: kaolinite (50), vermiculite (50) [26].

Mixtures were homogenized, milled for $20 \mathrm{~min}$ in ball mill and sintered at $1300^{\circ} \mathrm{C}$ for 1 hour, and then the cooling for ca. 10 hours.

\section{Cordierites based on the different vermiculites in mixtures}

Cordierites based on vermiculites, samples named here L, B, S, P and C, were sintered from the powder cordierite mixture containing talc (40 mass \%), kaolinite (47 mass \%) and vermiculite (13 mass \%) instead of alumina [21]. Vermiculites (Ver) from different commercial deposits were applied always in the same quantity.

The average crystal chemistry formulas of vermiculites (Table 1) show a variable substitution of $\mathrm{Fe}^{3+}$ and $\mathrm{Fe}^{2+}$ in octahedra and $\mathrm{Na}^{+}, \mathrm{K}^{+}$and $\mathrm{Ca}^{2+}$ in the interlayer space and indicate deviation from the pure Mg-vermiculite. According to the XRD analysis, diffraction patterns of Ver-B and Ver-L were very similar to the Mgvermiculites. Other Ver-S, Ver-P and Ver-C were mixed layered mica-vermiculites.

Structures of cordierites based on vermiculites can be compared with the selected from literature data about 26 natural orthorhombic and synthetic hexagonal cordierites, containing similar elements in the structure as studied vermiculites (Table 2).

The six crystals of cordierites from metamorphic rocks of the Bergel Alps are Nos. 1 to 6 with $\mathrm{Fe} /(\mathrm{Fe}+\mathrm{Mg}$ ) ranging from 0.07 to 0.42 (p.f.u) [36]. The single crystals of cordierites Nos. 7 to 10 from volcanic rocks of Tuscany and Lipary (Italy) were analyzed in the structure of Fe-rich cordierites [9]. Cordierites natural grains Nos. 11 to 20 were selected from various host rocks in the range of the atomic ratio of elements $(\mathrm{Fe}+\mathrm{Mn}) /(\mathrm{Fe}+\mathrm{Mn}+\mathrm{Mg})$ from 0.046 to 0.898 (p.f.u) [37]. The representatives of natural hexagonal cordierites are three indialites: No. 21, occurring in xenolithic rocks of Somma-Vesuvius volcano (Italy) with significant content of potassium [38], No. 22 from coal seams at Bokaro (India) [8], and No. 23 from the metamorphic cordierite-sillimanite rock complexes [39]. The synthetic hexagonal cordierites prepared from the cordierite glasses using sol-gel process are: No. 24 [40], No. 25 [41] and No. 26 [42].

\section{RESULTS AND DISCUSSION}

The previous studies showed that the substitution $\mathrm{Fe}^{2+}$ and $\mathrm{Mn}^{2+}$ for $\mathrm{Mg}^{2+}$ caused the increase of the octahedral volume of cordierite [43]. The increased content of Fe influenced the channels to move apart and rotate and move closer together within each channel resulting in decrease of the unit cell parameter $c$ [36].

The linear regression analyses of the natural orthorhombic cordierite samples Nos. 1-20 showed an appropriate correlation (Figure 2) between parameter $a$ (Figure 2a) and an inverse correlation between parameter $c$ (Figure 2b) and the corresponding Fe and $\mathrm{Mg}$ ratio $\mathrm{F}=(\mathrm{Fe}+\mathrm{Mn}) /(\mathrm{Fe}+\mathrm{Mn}+\mathrm{Mg})$.

The XRD patterns of the synthetic cordierites based on vermiculite samples are very similar (Figure 3 ). The maxima positions $2 \theta\left(^{\circ}\right)$ of reflections and assigned

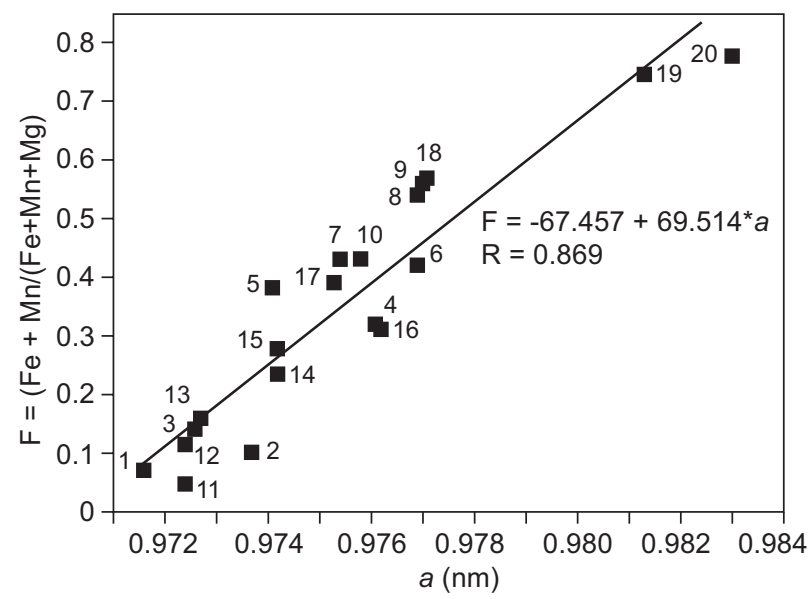

a) parameter $a$

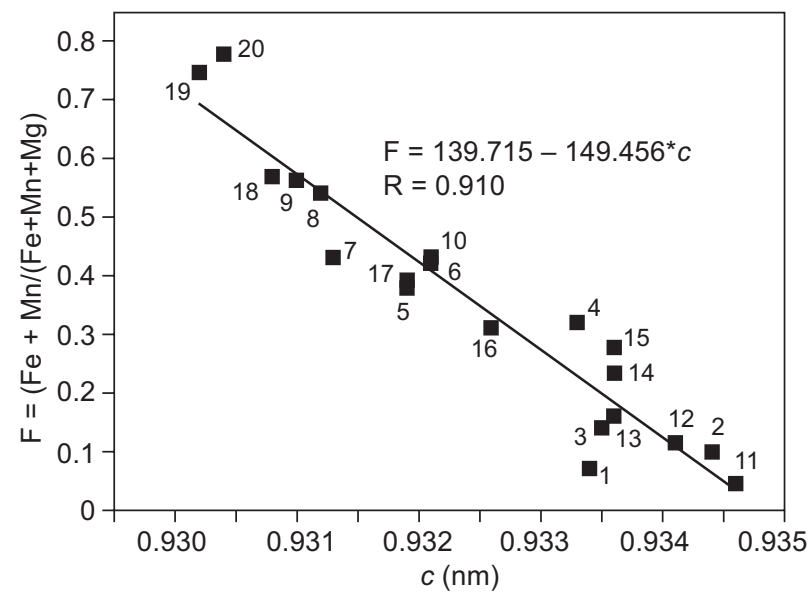

b) parameter $c$

Figure 2. The orthorhombic unit cell parameters vs. atomic ratio $\mathrm{F}=(\mathrm{Fe}+\mathrm{Mn}) /(\mathrm{Fe}+\mathrm{Mn}+\mathrm{Mg})$ (p.f.u.) in the natural cordierites Nos. 1-20 (Table 2): a) parameter $a$; b) parameter $c$. 
indexes $(\mathrm{hkl})_{\text {hex }}$ in the hexagonal symmetry (Figure 3a) were used to calculate the unit cell parameters (Figure 4).

The reflection region between $2 \theta=29$ and $30^{\circ}$ is characteristic for an intermediate crystalline phases between indialite highest disorder and cordierite high degree of order and calculation of distortion index $\Delta$ [44]. Cordierites based on vermiculite showed here one single peak with the wide and asymmetrical profile (Figure $3 \mathrm{~b}$ ). For the sake of lucidity, in this region are indicated: the position of $(211)_{\text {hex }}$ peak at $29.5^{\circ} 2 \theta$ calculated from the refinement structural data [41] and the positions of (511) orth at $29.36^{\circ} 2 \theta,(421)_{\text {orth }}$ at $29.45^{\circ} 2 \theta$ and $(131)_{\text {orth }}$ at $29.62^{\circ}$ according to the structural data [42]. Putnis and Bish [45] characterized according to the no splitting peak (211) on the XRD pattern and characteristic orthorhombic waves in TEM the intermediate modulated cordierite microstructure. Authors studied using the combination of XRD, TEM and IR techniques the mineral phases

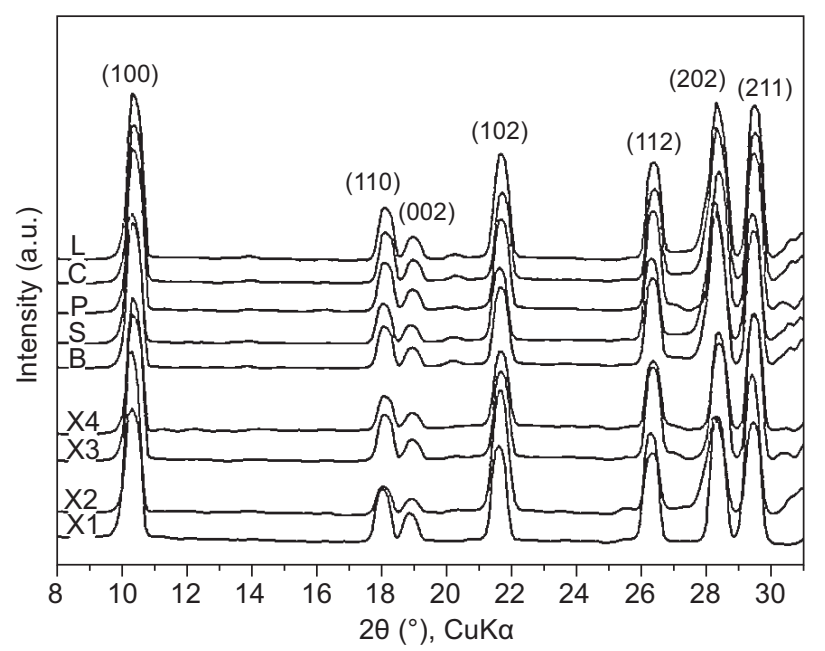

a)

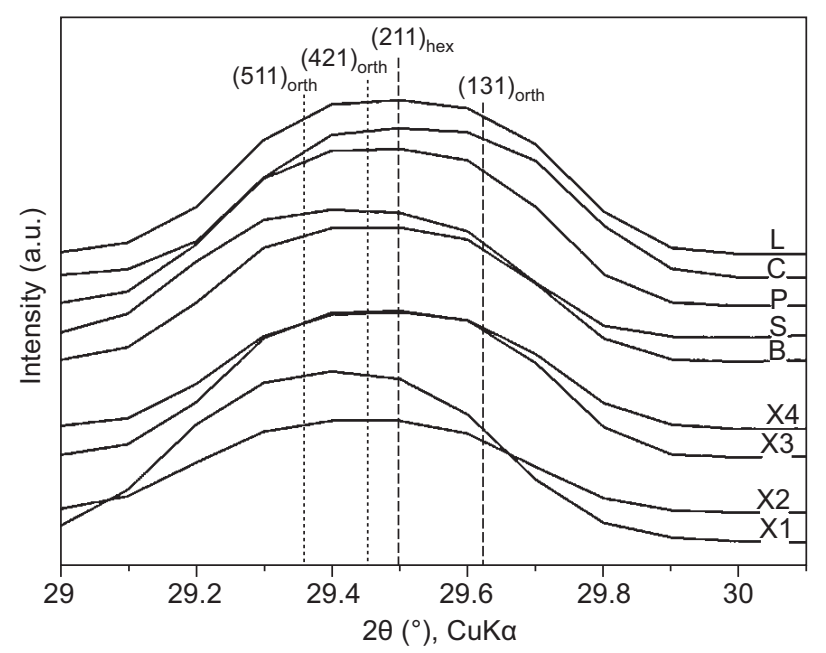

b)

Figure 3. The XRD powder patterns of cordierite based on vermiculite samples: a) The reflections with assigned (hkl) indices; b) The indicated peak positions of (211) hex and (511) orth, (421) orth and (131) orth in the range $2 \theta$ from 29 to $30^{\circ}$. crystallizing from the stoichiometric $\mathrm{Mg}$-cordierite glass by annealing at temperatures between $1050^{\circ} \mathrm{C}$ and $1445^{\circ} \mathrm{C}$ for periods from 30 seconds to 1000 hours. The first crystallization product was hexagonal cordierite which on annealing transformed to orthorhombic cordierite. After 3 hours of annealing, the onset of a modulated cordierite micro-structure was observed. Cordierites based on vermiculites were obtained from the sintering pre-ceramic mixtures at similar conditions ( 1 hour at $1300^{\circ} \mathrm{C}$ and the cooling for ca. 10 hours) $[26,35]$ and crystallization of modulated microstructures can be anticipated. According to the XRD patterns, the no splitting $(211)_{\text {hex }}$ peak and wide profiles of cordierite based on vermiculite samples (Figure $3 b$ ) may mask low-intensive orthorhombic peaks. Owing to the unidentifiable in the XRD patterns orthorhombic reflections, which signalize slight inclination from the hexagonal symmetry in the modulated cordierite structures, deviation from hexagonal symmetry by the distortion index $\Delta$ cannot be determined.

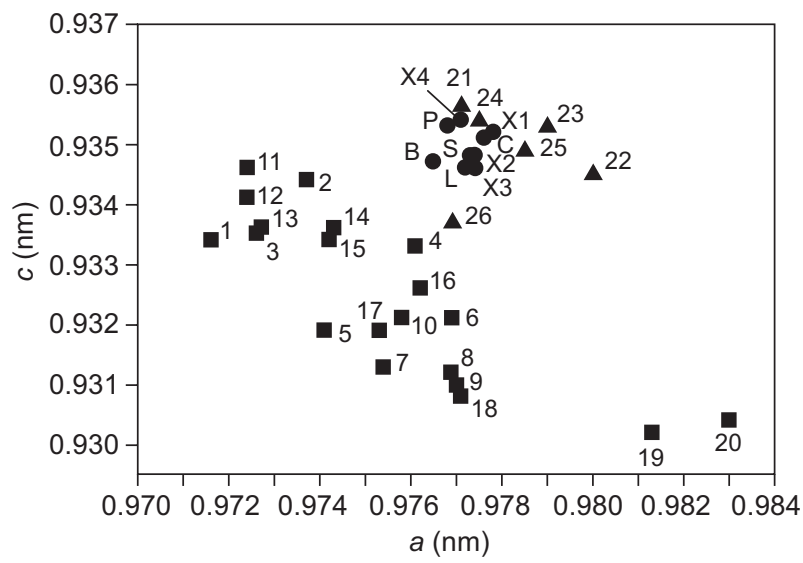

Figure 4. The unit cell parameters $a$ vs. $c$ for cordierites: Natural orthorhombic (Nos. 1-20); Natural hexagonal (Nos. 21, 22 and 23); Synthetic hexagonal (Nos. 24, 25 and 26); Synthetic hexagonal L, B, S, P and C based on vermiculites Ver-L, Ver-B, Ver-S, Ver-P and Ver-C in mixtures; Synthetic hexagonal X1, $\mathrm{X} 2, \mathrm{X} 3$ and $\mathrm{X} 4$ based on the mixtures of different formulation containing vermiculite.

Graphical presentation of the unit cell parameters $a$ vs $c$ calculated for cordierites based on vermiculite and 26 published for natural and synthetic cordierites allows their comparison (Figure 4).

Cordierites L, B, S, P and C prepared from mixtures containing different vermiculites Ver-L, Ver-B, Ver-S, Ver-P and Ver-C, respectively, have a slightly lower cell edges $c$ and $a$ than hexagonal natural and synthetic indialites Nos. 21-25. In the case of vermiculites used in the pre-ceramic mixtures, the substituting elements in octahedra $(\mathrm{Fe} \text { and } \mathrm{Mg})_{(\mathrm{oct})}$ and interlayer space $\left.(\mathrm{Na}, \mathrm{K} \text {, and } \mathrm{Ca})_{(\mathrm{int})}\right)$ are released during the sintering into the melt and can take part in the crystallization of cordierites based on vermiculites. As has been estab- 
lished by several authors, the alkali ions $\mathrm{K}^{+}$and $\mathrm{Na}^{+}$ can enter into the structural channels of cordierite [46]; Ion $\mathrm{K}^{+}$is too large to be accommodated in the fourand six-coordinated sites and can be located within the cordierite large channels parallel the $c$ axis [7]; Partial incorporation of $\mathrm{Na}^{+}$in the center of the six-member ring of oxygen atoms causes the rings to predominantly compress along the $b$-axis [47].

Chemistry of various vermiculites, according to the atomic ratios $\mathrm{F}_{\mathrm{Ver}}=\left(\mathrm{Fe} /(\mathrm{Fe}+\mathrm{Mg})_{\text {oct }}+(\mathrm{K}+\mathrm{Na}+\mathrm{Ca})_{\text {int }}\right)$ per formula unit (p.f.u.), has small effect on the unit cell parameter $c$ in cordierites based on vermiculites (Figure 5). The $c$ values in cordierites L, B, S, P and C were in the range from $0.9346(7) \mathrm{nm}$ to $0.9353(9) \mathrm{nm}$ in a good linear relation with the $\mathrm{F}_{\mathrm{Ver}}$ calculated from 0.21 to 0.69 for corresponding vermiculites Ver-L, Ver-B, Ver-S, Ver-P, and Ver-C, respectively, in the pre-ceramic mixtures (Figure 5a). The maximal difference 0.0007 $\mathrm{nm}$ in parameter $c$ was between the cordierites $\mathrm{L}$ and $\mathrm{P}$ and is within the standard deviations calculated for each

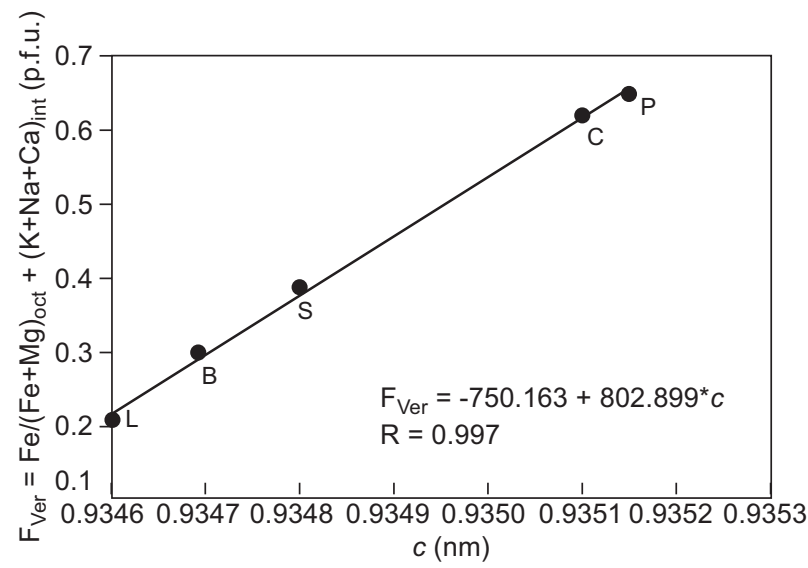

a)

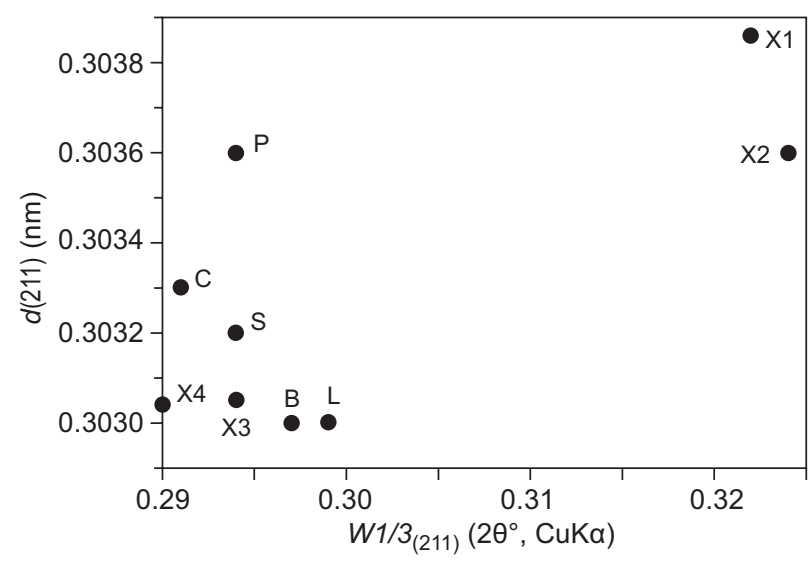

b)

Figure 5. Structural relation in cordierites based on vermiculites: a) The unit cell parameters $\mathrm{c}$ in cordierites $\mathrm{L}, \mathrm{B}, \mathrm{S}, \mathrm{C}$, and $\mathrm{P}$ as a function of the atomic ratio $\mathrm{F}_{\mathrm{Ver}}=\mathrm{Fe} /(\mathrm{Fe}+\mathrm{Mg})_{\text {oct }}+$ $+(\mathrm{K}+\mathrm{Na}+\mathrm{Ca})_{\text {int }}$ (p.f.u.) in vermiculites Ver-L, Ver-B, Ver-S, Ver-C and Ver-P; b) The width index $\mathrm{W} 1 / 3_{(211)}$ vs. interlayer value $d_{(211)}$ in cordierites. parameter $c$.

A more sensitive than distortion index $\Delta$ was designed the width index $W 1 / 3$, assayed at the one third of the maximum intensity of peak located near $29.5^{\circ} 2 \theta$ for $\mathrm{CuK} \alpha$ [48]. Authors [48] recommended the use of the index $W 1 / 3$ as a relative parameter for comparison of samples of known composition and thermal procedure. Cordierite based on vermiculite samples L, B, S, P, C, $\mathrm{X} 3$ and $\mathrm{X} 4$ showed a narrow range $W 1 / 3_{(211)}$ from $0.290^{\circ}$ to $0.299^{\circ} 2 \theta$. Exceeding of the range to the $W 1 / 3_{(211)}=$ $=0.322$ and $0.324^{\circ}$ was determined at samples X1 and $\mathrm{X} 2$, respectively, sintered from the mixtures containing also alumina (Figure 5b). According to the width index $W 1 / 3_{(211)}$ can be assumed that order-disorder of cordierites based on vermiculites is modulated highly disordered hexagonal and different from modulated structures of cordierites based on alumina.

\section{CONCLUSIONS}

Structural ordering of the 9 synthetic cordierites based on the commercial vermiculites was studied based on the X-ray powder diffraction data and compared with the literary 26 natural orthorhombic and synthetic hexagonal cordierites.

The slightly smaller than published hexagonal unit cell parameters of cordierites based on vermiculites were linearly dependent on the atomic ratio $\mathrm{F}_{\mathrm{Ver}}=(\mathrm{Fe} /$ $\left./(\mathrm{Fe}+\mathrm{Mg})_{\text {oct }}+(\mathrm{K}+\mathrm{Na}+\mathrm{Ca})_{\text {int }}\right)$ per formula unit (p.f.u.) of the corresponding vermiculites in the pre-ceramic mixtures.

Chemistry of various vermiculites, according to the atomic ratios $\mathrm{F}_{\mathrm{Ver}}=\left(\mathrm{Fe} /(\mathrm{Fe}+\mathrm{Mg})_{\text {oct }}+(\mathrm{K}+\mathrm{Na}+\mathrm{Ca})_{\text {int }}\right)$ per formula unit (p.f.u.), has small effect on the unit cell parameter $c$ in cordierites based on vermiculites. The maximal difference $0.0007 \mathrm{~nm}$ in parameter $c$ was within the standard deviations calculated for each parameter $c$.

The width index $W 1 / 3$ determined from (211) peak allowed separation of highly disordered hexagonal cordierites based on vermiculites from modulated structures of cordierites based on alumina.

Acknowledgment

Author thanks J. Kupková for measurement of XRD diffraction patterns and project "IT4Innovations excellence in science - LQ1602”.

\section{REFERENCES}

1. Rankin G.A., Merwin H.E. (1918): The ternary system $\mathrm{MgO}-\mathrm{Al}_{2} \mathrm{O}_{3}-\mathrm{SiO}_{2}$. American Journal of Science, 45, 301-325.

2. Miyashiro A., Iiyama T. (1954): A preliminary note on a new mineral, indialite, polymorphic with cordierite. Pro- 
ceedings of the Japan Academy, 30, 746-751. doi:10.2183/ pjab1945.30.746

3. Takane K., Takeuchi T. (1936): The crystal structure of cordierite. The Journal of the Japanese Association of Mineralogists, Petrologists, and Economic Geologists, 16, 101-127.

4. Byström A. (1942): The crystal structure of cordierite. Arkiv for Kemi Mineralogi och Geologi, 15B, 1-5.

5. Miyashiro A. (1957): Cordierite-indialite relations. American Journal of Science, 255, 43-62. doi:10.2475/ajs. 255.1 .43

6. Miyashiro A., Iiyama T., Yamasaki M., Miyashiro T. (1955): The polymorphism of cordierite and indialite. American Journal of Science, 253, 185-208. doi:10.2475/ ajs.253.4.185

7. Gibbs G.V. (1966): The polymorphism of cordierite: I. The crystal structure of low cordierite. American Mineralogist, 51, 1068-1087.

8. Meagher E.P., Gibbs G.V. (1977): The polymorphism of cordierite: II. The crystal structure of indialite. Canadian Mineralogist, 15, 43-49.

9. Armbruster T. (1985): Fe-rich cordierites from acid volcanic rocks, an optical and X-ray single-crystal study. Contributions to Mineralogy and Petrology, 91, 180-187.

10. Daniels P. (1990): What is the true space group of high-cordierite? Zeitschrift für Kristallographie - Crystalline Materials, 190, 271-276. doi:10.1524/zkri.1990.190.3-4.271

11. Putnis A. (1992). Introduction to Mineral Sciences. Cambridge University Press.

12.Putnis A., Salje E., Redfern S.A.T., Fyfe C., Strobl H. (1987): Structural states of Mg-cordierite: order parameters from synchrotron X-ray and NMR data. Physics and Chemistry of Minerals, 14, 446-454.

13.Güttler G., Salje E., Putnis A. (1989): Structural state of Mg-cordierite III: infrared spectroscopy and the nature of the hexagonal modulated transition. Physics and Chemistry of Minerals, 16, 365-373.

14.Redfern S.A.T., Saljie E., Maresch W., Schreyer W. (1989): X-ray powder diffraction and infrared study of the hexagonal to orthorhombic phase transition in K-bearing cordierite. American Mineralogist, 74, 1293-1299.

15. Malcherek T., Domeneghetti M.C., Tazzoli V., Ottolini L., McCammon C., Carpenter M.A. (2001): Structural properties of ferromagnesian cordierites. American Mineralogist, 86, 66-79. doi:10.2138/am-2001-0108

16. Toropov N.A., Barzakovskii V.P. (1966): Stable and Metastable Phase Relations in the System Magnesium Oxide-Alumina-Silica pp. 25-44 in: High-temperature chemistry of silicates and other oxide systems. Consultants Bureau A Division of Plenum Publishing Corporation New York.

17. Schreyer W., Schairer J.F. (1961): Composition and structural states of anhydrous cordierites: A re-investigation of the central part of the system $\mathrm{MgO}-\mathrm{Al}_{2} \mathrm{O}_{3}-\mathrm{SiO}_{2}$. Journal of Petrology, 2, 322-406. doi:10.1093/petrology/2.3.324

18. Valášková M. (2015): Clays, clay minerals and cordierite ceramics - A review. Ceramics-Silikáty, 59, 331-340.

19. Simha Martynková G., Valášková M. (2011). Vermiculite in nanocomposites, in: Nalwa H.S. (Ed.): Encyclopedia of Nanoscience and Nanotechnology. ASP 2011, pp. 119-145.

20.Valášková M., Simha Martynková G. (2012). Vermiculite: structural properties and examples of the use, in: Valášková, M., Simha Martynková, G. (Eds.) Clay Minerals in Nature, Their Characterization, Modification and Application,
InTech 2012, pp. 209-238.

21.Valášková M., Zdrálková J., Simha Martynková G., Smetana B., Vlček J., Študentová S. (2014): Structural variability of high purity cordierite/steatite ceramics sintered from mixtures with various vermiculites. Ceramics International, 40, 8489-8498. doi:10.1016/j. ceramint.2014.01.060

22. Marcos C., Arango Y.C., Rodriguez I. (2009): X-ray diffraction studies of the thermal behaviour of commercial vermiculites. Applied Clay Science, 42, 368-378. doi:10.1016/j.clay.2008.03.004

23. Okada K. Matsui S., Isobe T., Kameshima Y., Nakajima A. (2008): Water-retention properties of porous ceramics prepared from mixtures of allophane and vermiculite for materials to counteract heat island effects. Ceramics International, 34, 345-350. doi:10.1016/j.ceramint.2006. 10.006

24. Shirozu H., Bailey SW. (1966): Crystal structure of a two-layer Mg-vermiculite. American Mineralogist, 51, 1124-1143.

25.Guggenheim S., Adams J.M., Bain D.C., Bergaya F., Brigatti M.F., Drits V.A., Formoso M.L.L., Galán E., Kogue T., Stanjek H. (2006): Summary of recommendations of nomenclature committees Relevant to clay mineralogy: Report of the Association Internationale Pour l'Etude des Argiles (aipea) nomenclature committee for 2006. Clays and Clay Minerals, 54, 761-772. doi:10.1346/ccmn.2006. 0540610

26. Valášková M., Simha Martynková G., Zdrálková J., Vlček J., Matějková P. (2012): Cordierite composites reinforced with zircon arising from zirconium-vermiculite precursor. Materials Letters, 80, 158-161. doi:10.1016/j. matlet.2012.04.097

27.Valášková M., Tokarský J., Hundáková M., Zdrálková J., Smetana B. (2013): Role of vermiculite and zirconiumvermiculite on the formation of zircon-cordierite nanocomposites. Applied Clay Science, 75-76, 100-108, doi:10.1016/j.clay.2013.02.015

28.Valášková M., Kočí K., Kupková J. (2015): Cordierite/ steatite $/ \mathrm{CeO}_{2}$ porous materials - preparation, structural characterization and their photocatalytic activity. Microporous and Mesoporous Materials, 207, 120-125, doi:10.1016/j.micromeso.2014.12.035

29. Valášková M., Zdrálková J., Tokarský J., Simha Martynková G., Ritz M., Študentová S. (2014): Structural characteristics of cordierite/steatite ceramics sintered from mixtures containing pore-forming organovermiculite. Ceramics International, 40, 15717-15725. doi:10.1016/j. ceramint.2014.07.095

30. Seghedi A. (2012): Palaeozoic formations from Dobrogea and Pre-Dobrogea - an Overview. Turkish Journal of Earth Sciences, 21, 669-721. doi:10.3906/yer-1101-20.

31.Alves A.P.M., Fonseca M.G., Wanderley A.F. (2013): Inorganic-organic hybrids originating from organosilane anchored onto leached vermiculite. Material ResearchIbero-American Journal of Materials, 16, 891-897. doi:10.1590/S1516-14392013005000076.

32. Muiambo H.F., Focke W.W., Atanasova M., van der Westhuizen I., Tiedt L.R. (2010): Thermal properties of sodium-exchanged palabora vermiculite. Applied Clay Science, 50, 51-57. doi: 10.1016/j.clay.2010.06.023

33. Sun B., Huang J., Wang C., Zhang J.. (2005): Genesis and metallogenic model of a super-large vermiculite deposit, Qieganbulak, Xinjiang, China. In: Mao J., Bierlein F.P., 
editors. Mineral Deposit Research: Meeting the Global Challenge. Proceedings of the $8^{\text {th }}$ Biennial SGA Meeting, 2005, Aug 18-21, Beijing, China. Berlin: Springer; p. $1073-1076$

34.Holland T.J.B., Redfern S.A.T. (1997): Unit cell refinement from powder diffraction data: the use of regression diagnostics. Mineralogical Magazine, 61, 65-77.

35. Valášková M., Simha Martynková G., Smetana B., Študentová S. (2009): Influence of vermiculite on the formation of porous cordierites. Applied Clay Science, 46, 196-201. doi:10.1016/j.clay.2009.08.003.

36. Wallace J.H., Wenk H.R. (1980): Structure variation in low cordierites. American Mineralogist, 65, 96-111.

37.Selkregg K.R., Bloss F.D. (1980): Cordierites: compositional controls of $\Delta$, cell parameters, and optical properties. American Mineralogist, 65, 522-533.

38. Balassone G., Franco E., Mattia C.A., Puliti R. (2004): Indialite in xenolithic rocks from Somma-Vesuvius volcano (Southern Italy): Crystal chemistry and petrogenetic features. American Mineralogist, 89, 1-6. doi:10.2138/am2004-0101

39. Kumar Ramesh P.V., Raju K.K.V.S. (1997): Indialite from cordierite gneisses of Eastern Ghats Mobile Belt, India. Current Science, 73, 382-385.

40. Vepa S.S., Umarji A.M. (1993): Effect of substitution of $\mathrm{Ca}$ on thermal expansion of cordierite $\left(\mathrm{Mg}_{2} \mathrm{Al}_{4} \mathrm{Si}_{5} \mathrm{O}_{18}\right)$. Journal of the American Ceramic Society, 76, 1873-1876. doi:10.1111/j.1151-2916.1993.tb06664.x
41.Schwartz K.B., Leong D.B., McConville R.L. (1994): Structural chemistry of synthetic cordierite: Evidence for solid solutions and disordered compositional domains in bi-flux-grown $\mathrm{Mg}$-cordierites. Physics and Chemistry of Minerals, 20, 563-574.

42. Thomas P., Gouby I., Mercurio D., Merle T., Frit B. (1955): Synthesis and structural characterization of $\mathrm{Cu}[\mathrm{I}]$ and $\mathrm{Cu}[\mathrm{II}]$ - doped cordierites. Materials Research Bulletin, 30, 141-148.

43.Hochella Jr. M.F., Brown Jr. G.E., Ross F.K., Gibbs G.V. (1979): High-temperature crystal chemistry of hydrous Mg- and Fe-cordierites. American Mineralogist, 64, $337-$ 351.

44. Miyashiro A. (1957): Cordierite-indialite relations. American Journal of Science, 255, 43-62. doi:10.2475/ajs. 255.1.43

45.Putnis A., Bish D.L. (1983): The mechanism and kinetics of Al,Si ordering in Mg-cordierite. American Mineralogist, 68, 60-65.

46.Daniels P. (1992): Structural effects of the incorporation of large-radius alkalis in high cordierite. American Mineralogist, 77, 407-411

47. Armbruster T. (1986): Role of $\mathrm{Na}$ in the structure of lowcordierite:A single-crystal X-ray study. American Mineralogist, 71, 746-757.

48.Langer K., Schreyer W. (1969): Infrared and powder X-ray diffraction studies on the polymorphism of cordierite, $\mathrm{Mg}_{2}\left(\mathrm{Al}_{2} \mathrm{Si}_{5} \mathrm{O}_{18}\right)$. American Mineralogist, 54, 1442-1459. 